\title{
Clinical profile and pregnancy outcome following tubal recanalisation
}

\author{
Vilvapriya S. ${ }^{1}$, Veeraragavan K. ${ }^{2 *}$ \\ ${ }^{1}$ Department of Obstetrics and Gynecology, Govt Kilpauk Medical College Hospital, Kilpauk, Chennai, Tamil Nadu, \\ India \\ ${ }^{2}$ Department of Obstetrics and Gynecology, ESIC Hospital and Medical College, KK Nagar, Chennai, Tamil Nadu, \\ India
}

Received: 15 March 2018

Accepted: 21 April 2018

*Correspondence:

Dr. Veeraragavan K.,

E-mail: majorkvr@gail.com

Copyright: (C) the author(s), publisher and licensee Medip Academy. This is an open-access article distributed under the terms of the Creative Commons Attribution Non-Commercial License, which permits unrestricted non-commercial use, distribution, and reproduction in any medium, provided the original work is properly cited.

\section{ABSTRACT}

Background: Female sterilization by tubal ligation accounts for $36 \%$ of all methods of family planning used in our country. Almost half of tubal ligations are done in women younger than 25 years. These women want reversal of tubectomy subsequently, in circumstances like death of children, remarriage. This study aims to evaluate various factors affecting the outcome of pregnancies following microsurgical tubal recanalisation.

Methods: It is a prospective observational study carried out at Govt Kilpauk Medical College for a total number of 50 patients who have undergone tubal recanalisation during 2011 and 2012. They were followed up till December 2016.

Results: $84 \%$ of women (n-42) opted for recanalisation were in young reproductive age ( $<30$ years) group. Conception rate was higher in younger age group (52.9\% in 21-25 years). Death of children (n-37, 74\%) and remarriage $(\mathrm{n}-12,24 \%)$ were the common indications for tubal recanalisation. Outcome is better if reversal surgery is done within 4 years after sterilization $(69.6 \%, \mathrm{n}-16$ out of 23$)$ than after 4 years $(30.4 \%, \mathrm{n}-7$ out of 23$)$. Conception rate $(55.3 \%, \mathrm{n}-21)$ was higher and statistically significant in subjects with final length of tube more than $4 \mathrm{cms}(\mathrm{P}$ value -0.0193$)$. Conception rate was higher within 1 year of recanalisation $(n-13,26 \%)$, followed by $16 \%(n-8)$ in $2^{\text {nd }}$ year and statistically significant (p- 0.00001). Overall pregnancy rate in our study was 46\% (n-23). Out of the 23 women who conceived, $14(61 \%)$ resulted in live birth, $3(13 \%)$ abortions and the remaining $6(26 \%)$ had ectopic pregnancies.

Conclusions: Proper selection of patients and meticulous tuboplasty technique can yield successful pregnancy outcome comparable to ART.

Keywords: Tubal recanalisation, Tuboplasty, Tubectomy reversal

\section{INTRODUCTION}

Although wide ranges of contraceptive options are available, female tubal sterilization is currently the most common form of birth control. It is an important constituent of national family planning programme in India. According to NFHS-4 (2015-2016) female sterilization accounted for $36 \%$ of all methods family planning used in the country. ${ }^{1}$ More than $45.5 \%$ of women undergoing sterilization belong to young reproductive age group of 20-25 years. Approximately $1 \%$ of these women subsequently see reversal of procedure due to unforeseen circumstances like loss of child, remarriage and other socio economic factors. ${ }^{2}$ Patients who desire reversal of previous sterilization are served best by tubal anastomosis at laparotomy or by 
laparoscopic approach or by ART (assisted reproductive techniques). Microsurgical recanalisation procedures would bring hope to those in need of these services and would improve the confidence of clients who are acceptors of voluntary sterilization. Microsurgery remains an important operative technique for the management of tubal obstruction. In essence it involves magnification, the use of gentle tissue handling, fine sutures, meticulous hemostasis and copious irrigation with heparinised saline. ${ }^{3}$

Operative laparoscopy prevents drying of tissues, provides a degree of magnification, avoids use of packs and requires fewer days of postoperative hospitilisation ${ }^{3}$. Laparoscopic recanalisation has taken over conventional open microsurgical technique in west. Because of cost and technical restraints involved in laparoscopy, open method still remains a useful surgical option in developing countries like India. The Art of tubal surgery is in accurate diagnosis, careful case selection and meticulous surgical technique. The RCOG has recognised the value of tubal surgery and recommended that it should only be done in a few tertiary care centres. ${ }^{4}$

Recently there is an increasing trend of using ART techniques, but the cost factor restricts affordability by all. Tubal recanalisation is relatively cheap and also restores ability to achieve more than one pregnancy. This study is done to find whether open microsurgical tubal recanalisation can still be an option in the era of ART.

\section{Objectives}

This study aims to evaluate various factors affecting outcome of pregnancies following microsurgical tubal recanalisation.

\section{METHODS}

It is a prospective observational study carried out in a tertiary care centre, Govt Kilpauk Medical College for a total number of 50 patients who have undergone tubal recanalisation during 2011 and 2012. They were followed up till December 2016.

\section{Procedure}

Patients selected for sterlisation reversal were given counseling about surgery, its associated risks and outcome. For the subjects beside basic investigations, Diagnostic laparoscopy was done prior to reversal surgery to assess the pelvic anatomy. Semen analysis was done for male partners. Informed written consent was taken from both partners. Recanalisation surgery was done in follicular phase. Intra- operatively microscope is used for magnification, adhesions released electrosurgically, bipolar cautery used under continuous irrigation using heparinised saline, fibrosed ends were excised and re-anastomosis done taking sutures at 12', 6',
3' and 9' O clock positions using 8-0 ethilon. Tubal patency was checked by methylene blue dye injection, followed by thorough peritoneal saline wash. Then $32 \mathrm{mg}$ of injection Dexamethasone instilled in the peritoneal cavity as an adhesion barrier. Abdomen closed in layers. Careful monitoring was done in post operative period. Sexual intercourse was allowed after 2 months of surgery and if necessary induction of ovulation done.

\section{Inclusion criteria}

Inclusion criteria were death of one or more children; remarriage.

\section{Exclusion criteria}

Exclusion criteria were $>40$ years; medical (or) Surgical problems that endangers life during pregnancy; $\mathrm{B} / \mathrm{L}$ Hydrosalphinx (>3 cm) / severe adhesions; pelvic tuberculosis; severe endometriosis.

\section{RESULTS}

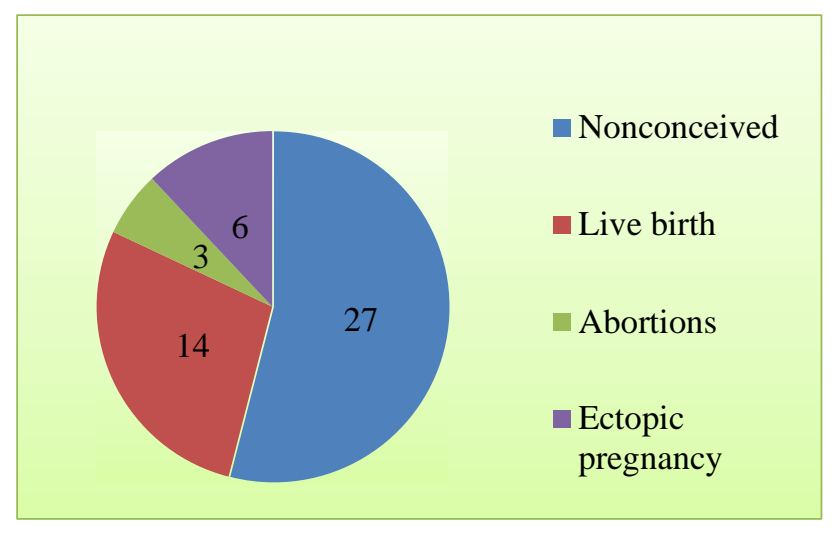

Figure 1: Surgical outcome.

50 women who underwent reversal of sterilization surgery were followed up for a period of 4-6 years. Most of the subjects $(n-42,84 \%)$ opted for recanalisation, were in young reproductive age $(<30$ years) group. Conception rate was higher in younger age group $(52.9 \%$ in 21 25 years, $48 \%$ in $26-30$ years), compared to advanced age ( $25 \%$ in $>30$ years). Death of children $(n-37,74 \%)$ and new marital relation $(n-12,24 \%)$ were the common reasons for tubal recanalisation. 48 patients had undergone open laparotomy previously for sterilization, puerperal sterilization in 28 patients $(56 \%)$, concurrent sterilization with LSCS in 15 patients $(30 \%)$ and interval transabdominal tubectomy in 5 patients(10\%). Only 2 of patients (4\%) had laparoscopic sterilization previously. Conception rate was higher $(66 \%, \mathrm{n}-10)$ in reversals who had concurrent sterilization with LSCS, followed by laparoscopic sterilization $(50 \%, \mathrm{n}-1)$ previously. Time interval between sterlisation and reversal has no statistical significance on pregnancy outcome in our study, but outcome is better if reversal surgery is done 
within 4 years after sterilization $(69.6 \%, n-16$ out of 23$)$ than after 4 years $(30.4 \%, n-7$ out of 23$)$. None out of 11 patients in isthmo-isthmic anastomosis, 3 patients out of 4 in bilateral cuff salphingostomy (75\%), 20 patients out of 35 in isthmo-ampullary anastomosis $(57.1 \%)$ conceived.(p value-0.0019, statistically significant). Conception rate $(55.3 \%, \mathrm{n}-21)$ was higher and statistically significant in subjects with final length of tube more than $4 \mathrm{cms}(\mathrm{p}=0.0193)$, compared to only
$16.7 \%$ conceptions (n-2) if length of tube was less than 4 cms. Observed conception rate was higher in the first year of recanalisation $(\mathrm{n}-13,26 \%)$, followed by $16 \%$ (n$8)$ in $2^{\text {nd }}$ year and statistically significant $(\mathrm{p}=0.00001)$. Overall pregnancy rate in our study was $46 \%$ (n-23). Out of the 23 women who conceived, $14(61 \%)$ resulted in live birth, 3 (13\%) abortions and the remaining $6(26 \%)$ had ectopic pregnancies.

Table 1: Age of the patients undergone tubal recanalization.

\begin{tabular}{|llllllll|}
\hline Age (yrs) & $\begin{array}{l}\text { Total no. Of } \\
\text { patients (n) } \\
(\%)\end{array}$ & Live births & Abortion & $\begin{array}{l}\text { Ectopic } \\
\text { pregnancy }\end{array}$ & $\begin{array}{l}\text { Conceived } \\
\mathbf{N}(\%)\end{array}$ & $\begin{array}{l}\text { Not } \\
\text { conceived } \\
\text { N }(\%)\end{array}$ & $\begin{array}{l}\text { Statistical } \\
\text { analysis }\end{array}$ \\
\hline $21-25$ & 17 & 5 & 1 & 3 & $9(52.9)$ & $8(47.1)$ & $\chi^{2}-1.7903$, \\
\hline $26-30$ & 25 & 8 & 2 & 2 & $12(48)$ & $13(52)$ & 0.40855 \\
p & 8 & 1 & 0 & 1 & $2(25)$ & $6(75)$ & not \\
Total & 50 & 14 & 3 & 6 & $23(46)$ & $27(54)$ & significant \\
\hline
\end{tabular}

Table 2: Parity of the patients undergone tubal recanalization.

\begin{tabular}{|llllllll|}
\hline Parity & $\begin{array}{l}\text { Total no. Of } \\
\text { patients }(\mathbf{n}) \\
(\%)\end{array}$ & Live births & Abortion & $\begin{array}{l}\text { Ectopic } \\
\text { pregnancy }\end{array}$ & $\begin{array}{l}\text { Conceived } \\
\mathbf{N}(\%)\end{array}$ & $\begin{array}{l}\text { Not } \\
\text { conceived } \\
\mathbf{N}(\%)\end{array}$ & $\begin{array}{l}\text { Statistical } \\
\text { analysis }\end{array}$ \\
\hline P2 & 49 & 14 & 3 & 5 & $22(44.9)$ & $27(55.1)$ & $\chi^{2}-1.1979$ \\
P3 & 1 & 0 & 0 & 1 & $1(100)$ & $0(0)$ & $\begin{array}{l}\text { P=0.2737, not } \\
\text { significant }\end{array}$ \\
\hline Total & 50 & 14 & 3 & 6 & $23(46)$ & $27(54)$ & \\
\hline
\end{tabular}

Table 3: Indications for tubal recanalization.

\begin{tabular}{|c|c|c|c|c|c|c|c|}
\hline $\begin{array}{l}\text { Indications for } \\
\text { recanalisation }\end{array}$ & $\begin{array}{l}\text { No of } \\
\text { patients } \\
(\%)\end{array}$ & $\begin{array}{l}\text { Live } \\
\text { births }\end{array}$ & Abortion & $\begin{array}{l}\text { Ectopic } \\
\text { pregnancy }\end{array}$ & $\begin{array}{l}\text { Conceived } \\
\mathbf{N}(\%)\end{array}$ & $\begin{array}{l}\text { Not } \\
\text { conceived } \\
\text { N }(\%)\end{array}$ & $\begin{array}{l}\text { Statistical } \\
\text { analysis }\end{array}$ \\
\hline Death of child & $37(74)$ & 10 & 2 & 4 & $16(43.2)$ & $21(56.8)$ & \multirow{4}{*}{$\begin{array}{l}\chi^{2}-1.699 \\
\text { P-0.4274, } \\
\text { not significant }\end{array}$} \\
\hline Remarriage & $12(24)$ & 4 & 1 & 2 & $7(58.3)$ & $5(41.7)$ & \\
\hline $\begin{array}{l}\text { Severe health } \\
\text { problem in the } \\
\text { child }\end{array}$ & $1(2)$ & 0 & 0 & 0 & $0(0)$ & $1(100)$ & \\
\hline Total & 50 & 14 & 3 & 6 & $23(46)$ & $27(54)$ & \\
\hline
\end{tabular}

Table 4: Previous sterilisation method.

\begin{tabular}{|c|c|c|c|c|c|c|c|}
\hline Previous surgery & $\begin{array}{l}\text { Total no. of } \\
\text { patients (n) }(\%)\end{array}$ & $\begin{array}{l}\text { Live } \\
\text { births }\end{array}$ & Abortion & $\begin{array}{l}\text { Ectopic } \\
\text { pregnancy }\end{array}$ & $\begin{array}{l}\text { Conceived } \\
\mathbf{N}(\%)\end{array}$ & $\begin{array}{l}\text { Not conceived } \\
\text { N }(\%)\end{array}$ & $\begin{array}{l}\text { Statistical } \\
\text { analysis }\end{array}$ \\
\hline $\begin{array}{l}\text { Puerperal sterilisation } \\
\text { (Pomeroy's) }\end{array}$ & $28(56)$ & 8 & 1 & 2 & $11(39.3)$ & $17(60.7)$ & \multirow{5}{*}{$\begin{array}{l}\chi^{2}-4.4609 \\
\mathrm{p}=0.2158 \\
\text { not } \\
\text { significant }\end{array}$} \\
\hline $\begin{array}{l}\text { Interval trans } \\
\text { abdominal tubectomy } \\
\text { (Pomeroy's) }\end{array}$ & $5(10)$ & 1 & 0 & 0 & $1(20)$ & $4(80)$ & \\
\hline $\begin{array}{l}\text { LSCS With } \\
\text { sterilisation } \\
\text { (Pomeroy's) }\end{array}$ & $15(30)$ & 4 & 2 & 4 & $10(66.7)$ & 05 (33.3) & \\
\hline Lap sterilisation & $2(4)$ & 1 & 0 & 0 & $1(50)$ & $1(50)$ & \\
\hline Total & 50 & 14 & 3 & 6 & $23(46)$ & $27(54)$ & \\
\hline
\end{tabular}


Table 5: Interval between sterilisation and reversal.

\begin{tabular}{|llllllll|}
\hline $\begin{array}{l}\text { Time interval } \\
\text { (months) }\end{array}$ & $\begin{array}{l}\text { Total no of } \\
\text { patients } \\
\text { (n) }\end{array}$ & $\begin{array}{l}\text { Live } \\
\text { births }\end{array}$ & Abortion & $\begin{array}{l}\text { Ectopic } \\
\text { pregnancy }\end{array}$ & $\begin{array}{l}\text { Conceived } \\
\mathbf{N}(\%)\end{array}$ & $\begin{array}{l}\text { Not } \\
\text { conceived } \\
\mathbf{N}(\%)\end{array}$ & $\begin{array}{l}\text { Statistical } \\
\text { analysis }\end{array}$ \\
\hline $0-12$ & 5 & 1 & 0 & 0 & $1(20)$ & $4(80)$ \\
\hline $13-24$ & 11 & 2 & 1 & 2 & $5(45.4)$ & $6(54.6)$ & $\chi^{2}-3.9254$, P- \\
\hline $25-36$ & 12 & 4 & 0 & 2 & $6(50)$ & $6(50)$ & 0.4161 , not \\
\hline $37-48$ & 5 & 0 & 2 & 2 & $4(80)$ & $1(20)$ & $10(58.8)$ \\
\hline$>48$ & 17 & 7 & 0 & 0 & $7(41.2)$ & $27(54)$ \\
\hline Total & 50 & 14 & 3 & 6 & $23(46)$ &
\end{tabular}

Table 6: Site of anastomosis.

\begin{tabular}{|c|c|c|c|c|c|c|c|}
\hline Site & $\begin{array}{l}\text { No of } \\
\text { patients }\end{array}$ & $\begin{array}{l}\text { Live } \\
\text { births }\end{array}$ & Abortion & $\begin{array}{l}\text { Ectopic } \\
\text { pregnancy }\end{array}$ & $\begin{array}{l}\text { Conceived } \\
\text { N }(\%)\end{array}$ & $\begin{array}{l}\text { Not } \\
\text { conceived } \\
\text { N }(\%)\end{array}$ & $\begin{array}{l}\text { Statistical } \\
\text { analysis }\end{array}$ \\
\hline $\begin{array}{l}\text { Isthmus- } \\
\text { isthmus }\end{array}$ & 11 & 0 & 0 & 0 & $0(0)$ & $11(100)$ & \multirow{4}{*}{$\begin{array}{l}\chi^{2}-12.4741, \mathrm{P}- \\
0.0019, \\
\text { statistically } \\
\text { significant }\end{array}$} \\
\hline $\begin{array}{l}\text { B/l cuff } \\
\text { salphingostomy }\end{array}$ & 4 & 2 & 0 & 1 & $3(75)$ & $1(25)$ & \\
\hline $\begin{array}{l}\text { Isthmus- } \\
\text { ampulla }\end{array}$ & 35 & 12 & 3 & 5 & $20(57.1)$ & $15(42.9)$ & \\
\hline Total & 50 & 14 & 3 & 6 & $23(46)$ & $27(54)$ & \\
\hline
\end{tabular}

Table 7: Final length of the tube.

\begin{tabular}{|c|c|c|c|c|c|c|c|}
\hline $\begin{array}{l}\text { Final length of } \\
\text { tube }\end{array}$ & $\begin{array}{l}\text { Total no of } \\
\text { patients(n) }\end{array}$ & $\begin{array}{l}\text { Live } \\
\text { births }\end{array}$ & Abortion & $\begin{array}{l}\text { Ectopic } \\
\text { pregnancy }\end{array}$ & $\begin{array}{l}\text { Conceived } \\
\mathbf{N}(\%)\end{array}$ & $\begin{array}{l}\text { not } \\
\text { conceived } \\
\text { N }(\%)\end{array}$ & $\begin{array}{l}\text { Statistical } \\
\text { analysis }\end{array}$ \\
\hline$\leq 4 \mathrm{~cm}$ & 12 & 0 & 0 & 2 & $2(16.7)$ & $10(83.3)$ & \multirow{3}{*}{$\begin{array}{l}\chi^{2}-5.4694, \mathrm{P}- \\
0.0193, \\
\text { statistically } \\
\text { significant }\end{array}$} \\
\hline$>4 \mathrm{~cm}$ & 38 & 14 & 3 & 4 & $21(55.3)$ & $17(44.7)$ & \\
\hline Total & 50 & 14 & 3 & 6 & $23(46)$ & $27(54)$ & \\
\hline
\end{tabular}

Table 8: Time of conception since tubal recanalization.

\begin{tabular}{|c|c|c|c|c|c|c|}
\hline $\begin{array}{l}\text { Time since } \\
\text { recanalisation ( in } \\
\text { months) }\end{array}$ & Live births & Abortion & $\begin{array}{l}\text { Ectopic } \\
\text { pregnancy }\end{array}$ & $\begin{array}{l}\text { Conceived } \\
\mathbf{N}(\%)\end{array}$ & $\begin{array}{l}\text { Not conceived } \\
\text { N }(\%)\end{array}$ & $\begin{array}{l}\text { Statistical } \\
\text { analysis }\end{array}$ \\
\hline $0-12$ & 6 & 2 & 5 & $13(26)$ & $0(0)$ & \multirow{4}{*}{$\begin{array}{l}\chi^{2}-42.5037 \\
\text { P-0.00001, } \\
\text { statistically } \\
\text { significant }\end{array}$} \\
\hline $13-24$ & 6 & 1 & 1 & $8(16)$ & $0(0)$ & \\
\hline$>24$ & 2 & 0 & 0 & $2(04)$ & $27(54)$ & \\
\hline Total & 14 & 3 & 6 & $23(46)$ & $27(54)$ & \\
\hline
\end{tabular}

Table 9: Outcome of conceptions following tubal recanalization.

\begin{tabular}{|llll|}
\hline Total conceptions & Live birth & abortion & Ectopic pregnancy \\
\hline 23 & $14(61 \%)$ & $3(13 \%)$ & $6(26 \%)$ \\
\hline
\end{tabular}

\section{DISCUSSION}

Tubectomy is the most commonly accepted sterilization procedure in Indian women. Most of the tubectomies are carried out in young reproductive mothers after completion of family. Government of India promotes sterilisation through national post partum family planning programme. Some women regret sterilisation in situations like death of children, remarriage and severe medical disorders in living children.

Reversal of tubectomy by tubal microsurgery gives hope for these women to have their biological children. Success of this tubal recanalisation depends on various 
factors i.e. age of the patient, final length of tube, type of anastomosis, previous surgical method used for sterilization, latency between tubectomy and reversal surgery, pelvic adhesions and co-morbid conditions.

Table 10: Comparing present study with other observers.

\begin{tabular}{|llllll|}
\hline Factors & Present study & Rivai $^{5}$ & MN $^{2}$ & Jain $^{6}$ & Ramalingappa $^{7}$ \\
\hline Conception rate & 46 & 34.5 & 55.5 & 75 & 44 \\
\hline Ectopic pregnancy rate & 26 & 15.8 & 12 & 3.33 & 9 \\
\hline Conceptions in Tubal length>4cm & 55.3 & 46.1 & 64.8 & 74.3 & 50 \\
\hline Conceptions in Tubal length<4cm & 16.7 & 4.8 & 12.5 & 9.09 & - \\
\hline conception in post lapster recanalisation & 50 & 3.38 & 62.9 & 68.5 & 50 \\
\hline Conceptions in pomeroy's ligation recanalisation & 45.8 & 96.6 & 44.4 & 40 & 30 \\
\hline Conceptions in isthmo-ampullary anastomosis & 57.1 & 42.1 & 38.8 & 20 & 50 \\
\hline
\end{tabular}

In the present study $84 \%$ of the women who underwent tuboplasty were in $<30$ years age. Conception rate shows decreasing trend towards advancing age $(52.9 \%$ in 21 25 years, $48 \%$ in $26-30$ years \& $25 \%$ in $>30$ years). Death of children (74\%) and willingness to have biological child through remarriage $(24 \%)$ were the common reasons to seek tubectomy reversal.

In our series, 48 women (96\%) had sterilization through open laparotomy by Pomeroy's technique - i.e. minilaparotomy for puerperal sterilization (56\%), interval sterilization (10\%) and concurrent sterilization with LSCS (30\%) and lapsterilisation were only in 2 patients $(4 \%)$. We observed $66 \%$ conception rate in reversals who had concurrent sterilization with LSCS, followed by $50 \%$ conception in reversal of laparoscopic sterilization. We are not able to see statistical significance since number of patients (n-2, 4\%) undergone post lapsterilisation reversal is less. Though it is statistically not significant, reversal done earlier within 4 years of sterilization surgery had higher conception rate $(69.6 \%)$ than after 4 years $(30.4 \%)$. Contrary to other observers, conception rate was higher in isthmoampullary anaestomosis $(57.1 \%)$ and no conceptions observed in isthmo-isthmic anaestomosis where others had high conception rate.

We had 3 conceptions (75\%) in 4 women who underwent cuff salphingostomy, higher than other observers. In our series also outcomes were comparable with others, when tubal length was more than $4 \mathrm{cms}$ and statistically significant. Overall pregnancy rate in our study was $46 \%$ (n-23). Out of the 23 women who conceived, 14 (61\%) resulted in live birth, $3(13 \%)$ abortions and the remaining $6(26 \%)$ had ectopic pregnancies. Of the 23 conceptions, 13 were observed in $1^{\text {st }}$ year, 8 conceptions in $2^{\text {nd }}$ year and remaining 2 in $3^{\text {rd }}$ year showing significant success in earlier years following surgery. Our live birth rate $(61 \%)$, abortion rate $(13 \%)$ was comparable with other studies. Our ectopic pregnancy rate $(26 \%)$ was higher than other studies.
Proper selection of patients and meticulous tuboplasty technique can yield successful pregnancy outcome comparable to ART.

This marvelous technique of tubal recanalisation refined by Winstone and Gomel should not be lost in the wake of ART. ${ }^{8}$ Since there is a possibility of every sterilized woman to seek reversal of tubectomy, we have to strictly adhere to guidelines on standards of sterilisation issued by Govt. of India, for better outcome. ${ }^{9}$

\section{CONCLUSION}

Microsurgical tubal recanalisation should be offered as first option for properly selected desperate couples. Meticulous surgical technique and tissue respect will definitely yield outcome comparable to ART at a much lower cost. Though microsurgical technique has its own limitation, it has brought a ray of hope to women seeking sterilization reversal.

Tubal microsurgery and ART techniques are complimentary approaches to optimize a women's reproductive potential. Tubal microsurgery technique should be made available in all tertiary care institutions and adequate training should be imparted to gynaecologists interested in fertility enhancing surgeries.

\section{ACKNOWLEDGMENTS}

Authors are extremely thankful to Mr. S. Padmanaban, NIRRH field Unit, ICMR, Govt Kilpauk Medical College Hospital in statistical analysis. Authors acknowledge the scholars whose articles are cited in references of this manuscript.

Funding: No funding sources Conflict of interest: None declared

Ethical approval: The study was approved by the Institutional Ethics Committee 


\section{REFERENCES}

1. National Family Health Survey 4 (2015-16) Ministry of health and Family welfare, Govt. of India. Available at http://www. rchiips.org/nfhs4. Accessed 03 March 2017.

2. Shilpa MN, B Shilpa Shivanna: Correlation of prognostic factors and outcome of microsurgical tubal recanalisation. IOSR Journal of dental and medical sciences, 2014;13(9):13-5.

3. Siegler AM, Siegler A, Glob. Libr: Microsurgical tubal Reconstruction. Women's med DOI10.3843/GLOWM./0045 (ISSN; 1756-2228)2008. Accessed 03 March 2017.

4. Gavin S, Geoff T. Review -Reconstruction, destruction and IVF - dilemmas in the art of tubal surgery. BJOG. 2004;3(11):1174-81.

5. Rizvi S, Jafri A, Haidar R. Tubal sterilization reversal - Is there any role in the modern era of ART? Annals. 2015;21(4).
6. Jain M, Jain P, Garg R. Microsurgical tubal recanalisation: A hope for hopeless. Indian J Plast Surg. 2003;36(2):66-70.

7. Yashoda RA. A Study on Tubal Recanalization. J Obstet Gynaecol India. 2012;62(2):179-83.

8. Gomel V. Microsurgical reversal of female sterisation: A reappraisal. Femil Sterl. 1980;33:58797.

9. Standards for male and female Recanalisation, Technical operations division, Department of family welfare, Ministry of Health and Female welfare, Govt. of India; 1990: 1-26.

Cite this article as: Vilvapriya S, Veeraragavan K. Clinical profile and pregnancy outcome following tubal recanalisation. Int J Reprod Contracept Obstet Gynecol 2018;7:2239-44. 